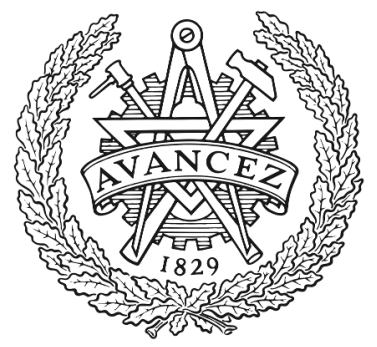

CHALMERS

UNIVERSITY OF TECHNOLOGY

\title{
Utilization of promising calcium manganite oxygen carriers for potential thermochemical energy storage application
}

Downloaded from: https://research.chalmers.se, 2023-04-26 06:18 UTC

Citation for the original published paper (version of record):

Yilmaz, D., Darwish, E., Leion, H. (2021). Utilization of promising calcium manganite oxygen carriers for potential thermochemical energy storage application. Industrial \& Engineering Chemistry Research, 60(3): 1250-1258. http://dx.doi.org/10.1021/acs.iecr.0c05182

N.B. When citing this work, cite the original published paper. 


\title{
Utilization of Promising Calcium Manganite Oxygen Carriers for Potential Thermochemical Energy Storage Application
}

\author{
Duygu Yilmaz,* Esraa Darwish, and Henrik Leion
}

Cite This: Ind. Eng. Chem. Res. 2021, 60, 1250-1258

Read Online

ABSTRACT: In this study, oxygen release/consumption behavior of calcium manganese-based oxides $\left(\mathrm{CaMn}_{1-x} \mathrm{~B}_{x} \mathrm{O}_{3}\right.$, where $\mathrm{B}: \mathrm{Cu}, \mathrm{Fe}$, $\mathrm{Mg}$ and $x=0.1$ or 0.2 ) used in a chemical looping oxygen uncoupling (CLOU) application was investigated. The effect of B-site dopants such as $\mathrm{Fe}, \mathrm{Mg}$, and $\mathrm{Cu}$ on the oxygen release behavior was also investigated with the aim to use these materials in thermal energy storage (TES). Previous literature studies about CLOU performance of doped calcium manganites were taken into consideration for dopants selection. Calcium manganite-based oxides have been used in chemical looping oxygen uncoupling (CLOU) applications owing to their oxygen release behavior to the gas phase. Studies have revealed that calcium manganite-based oxides show a promising nonstoichiometry over a range of temperatures and oxygen partial

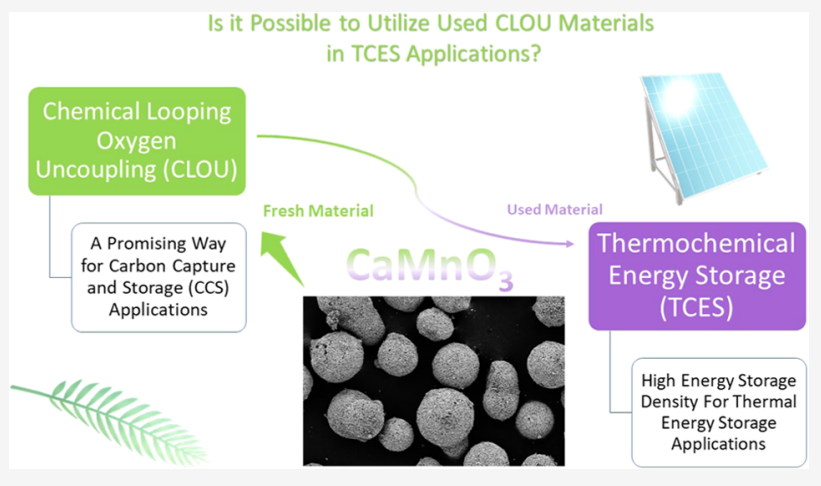
pressures, which makes them useful for thermochemical energy storage applications. However, the related literature studies have been mainly focused on their nonstoichiometric characteristics related to temperature and oxygen partial pressure and thermodynamic properties. In this work, thermal analysis and fluidized bed tests were carried out as complementary techniques. $\mathrm{CaMn}_{0.8} \mathrm{Cu}_{0.2} \mathrm{O}_{3}$ showed the highest oxygen release performance in fluidized bed tests, while $\mathrm{CaMn}_{0.9} \mathrm{Mg}_{0.1} \mathrm{O}_{3}$ had the best cyclic stability overall among the samples used in the study.

\section{INTRODUCTION}

Thermal energy storage (TES) is a necessary tool to reach the sustainable energy goals via green and sustainable energy resources. ${ }^{1}$ Continuous electricity production is important, and it only becomes possible with storing the energy during on-sun hours and releasing the stored energy during off-sun hours. ${ }^{2}$ Among the energy storage techniques, thermochemical energy storage (TCES) exhibits a significantly good performance regarding energy storage density $(0.5-1 \mathrm{kWh} / \mathrm{kg}))^{3}$ theoretically unlimited storage period or storage within a large temperature range $\left(25-1000{ }^{\circ} \mathrm{C}\right) .{ }^{4}$ Besides, there is no need to use specific and complex storage procedures as the heat is stored in the form of chemical energy in TCES. ${ }^{5}$ To store a high amount of energy, redox reactions of metal oxides can be useful since their operational temperatures are relatively high. ${ }^{6}$ From metal oxides, $\mathrm{Co}_{3} \mathrm{O}_{4}, \mathrm{CuO}, \mathrm{Fe}_{2} \mathrm{O}_{3}$, and $\mathrm{Mn}_{2} \mathrm{O}_{3}$ show remarkable performance to meet the expectations for TCES applications. ${ }^{7}$ Among these oxides, $\mathrm{Mn}_{2} \mathrm{O}_{3}$ is very promising since it is less expensive, more abundant, more cyclically stable, and environmentally friendly. ${ }^{8,9}$ Since the reoxidation rates of pure $\mathrm{Mn}_{3} \mathrm{O}_{4}$ to $\mathrm{Mn}_{2} \mathrm{O}_{3}$ are slightly slow, the combination of the $\mathrm{Mn}$ oxides was also tested in some studies to increase the performance of the $\mathrm{Mn}$ oxides for thermochemical energy storage applications. ${ }^{4,10-15}$ Especially, $\mathrm{Cu} / \mathrm{Mn}$ combined oxides showed a lower redox temperature than the pure $\mathrm{Cu}$ or $\mathrm{Mn}$ oxides. ${ }^{4,16}$ In addition, $\mathrm{Fe} / \mathrm{Mn}$ combined oxides also showed much faster reoxidation rates compared to pure $\mathrm{Mn}$ oxides. $^{10,13,16}$

In the literature, there are a few studies about $\mathrm{CaMnO}_{3}$ as a thermochemical energy storage material. ${ }^{17,18}$ These studies were focused on redox characteristics, redox chemistry, and oxygen nonstoichiometry of the material. ${ }^{17-20}$ However, there is no available systematic study about the effect of dopants on the oxygen release behavior of $\mathrm{CaMnO}_{3}$ so far.

However, Mn-based systems require performance improvement as they feature slow kinetics of the oxidation step. ${ }^{14}$ Slow kinetics of Mn-based system have also been seen in chemical looping oxygen uncoupling applications. ${ }^{21}$ To tackle this problem in chemical looping oxygen uncoupling (CLOU), Mn oxides have been combined with other oxides such as $\mathrm{SiO}_{2}$, $\mathrm{Fe}_{2} \mathrm{O}_{3}, \mathrm{MgO}$, and $\mathrm{CaO}^{22-24}$ Especially calcium manganesebased materials have shown great promise as the reactivity is high and estimated lifetime is long enough to be used in chemical looping oxygen uncoupling (CLOU) applica-

Received: October 23, 2020

Revised: January 5, 2021

Accepted: January 5, 2021

Published: January 13, 2021 
tions. $^{25-27}$ Calcium manganite, $\mathrm{CaMnO}_{3-\delta}$, has a perovskitetype structure and shows continuous nonstoichiometry with respect to oxygen. ${ }^{17}$ The $\delta$-factor defines the degree of oxygen deficiency in the structure. ${ }^{19,28}$ This characteristic enhances the oxygen mobility in the lattice, and it can release oxygen to the gas phase over a range of temperatures. ${ }^{29}$ These features raise $\mathrm{CaMnO}_{3}$ to be a perfect fit as a thermochemical energy storage material.

In this study, doped calcium manganite-based oxygen carriers used in methane reactivity tests ${ }^{29}$ were investigated as potential thermochemical energy storage materials. The effects of dopants such as $\mathrm{Cu}, \mathrm{Fe}$, and $\mathrm{Mg}$ on the oxygen release behavior of $\mathrm{CaMnO}_{3}$ were investigated systematically. The amount of dopant (A) was kept as $x=0.1$ or 0.2 where the sample composition was $\mathrm{CaMn}_{1-x} \mathrm{~A}_{x} \mathrm{O}_{3}(\mathrm{~A}: \mathrm{Fe}, \mathrm{Mg}, \mathrm{Cu}$ ). The effect of dopant combination such as $\mathrm{Cu}-\mathrm{Fe}$ and $\mathrm{Mg}-\mathrm{Ti}$ was also investigated.

\section{EXPERIMENTAL SECTION}

The oxygen carriers used in this study were produced by VITO (Flemish Institute for Technological Research) by the spraydrying method, and the materials were designed to have a molar composition of $\mathrm{CaMn}_{1-x} \mathrm{~A}_{x} \mathrm{O}_{3}$ (A: $\mathrm{Fe}, \mathrm{Mg}, \mathrm{Cu}, \mathrm{Cu} \& \mathrm{Fe}$, $\mathrm{Mg} \& \mathrm{Ti}$ ). The detailed synthesis conditions and the parameters related to the chemical looping oxygen uncoupling application, where the chosen calcium manganates were used as oxygen carriers, can be found elsewhere. ${ }^{29}$ The starting chemical compositions of the powders are given in Table 1. The phase

Table 1. Designed Chemical Composition and Notation of Samples Used in This Study ${ }^{a}$

\begin{tabular}{ll} 
sample $^{\text {ref work }}$ & \multicolumn{1}{c}{ composition } \\
$\mathrm{CM}^{30}$ & $\mathrm{CaMnO}_{3}$ \\
$\mathrm{CMF1}^{31}$ & $\mathrm{CaMn}_{0.9} \mathrm{Fe}_{0.1} \mathrm{O}_{3}$ \\
$\mathrm{CMF2}^{31}$ & $\mathrm{CaMn}_{0,8} \mathrm{Fe}_{0,2} \mathrm{O}_{3}$ \\
$\mathrm{CMM1}^{26,29,32}$ & $\mathrm{CaMn}_{0.9} \mathrm{Mg}_{0.1} \mathrm{O}_{3}$ \\
$\mathrm{CMM}^{29,32}$ & $\mathrm{CaMn}_{0.9} \mathrm{Mg}_{0.2} \mathrm{O}_{3}$ \\
$\mathrm{CMC1}$ & $\mathrm{CaMn}_{0,9} \mathrm{Cu}_{0,1} \mathrm{O}_{3}$ \\
$\mathrm{CMC2}$ & $\mathrm{CaMn}_{0,9} \mathrm{Cu}_{0,2} \mathrm{O}_{3}$ \\
$\mathrm{CMCF}$ & $\mathrm{CaMn}_{0.8} \mathrm{Cu}_{0.1} \mathrm{Fe}_{0.1} \mathrm{O}_{3}$ \\
$\mathrm{CMMT}$ & $\mathrm{CaMn}_{0.775} \mathrm{Mg}_{0.1} \mathrm{Ti}_{0.125} \mathrm{O}_{3}$
\end{tabular}

${ }^{a}$ Reference work ( ${ }^{\text {ref work }}$ ) refers to the published results with using the same composition in a CLOU operation.

analysis of the samples after having been used in CLOU applications (called fresh) and after the fluidized bed tests (called used) is given in the Supporting Information. The samples after having been used in CLOU applications were sieved into the $180-250 \mu \mathrm{m}$ size range to get rid of possible destroyed particles.

Characterization of the synthesized samples for phase analysis was done using an X-ray diffractometer (XRD, Bruker D8 Advance, $\mathrm{Cu} \mathrm{K} \alpha, 40 \mathrm{kV}, 40 \mathrm{~mA}$ ) in the $2 \theta$ range of $20-75^{\circ}$ with a step size of 0.01 . Phase analysis was conducted on samples before and after being used in the cyclic experiments. A scanning electron microscope (SEM, Zeiss LEO Ultra 55 FEG) was used to study the particle morphologies. Detailed information is given in the Supporting Information. For thermal analysis, a simultaneous thermal analyzer (STA)(Netzsch-STA 409 PC Luxx) was used to determine thermal behavior. For each experiment, the amount of sample was 70 mg. The samples were exposed to air and $\mathrm{N}_{2}$ during all oxidation cycles $\left(\mathrm{pO}_{2}: 0.21\right.$ atm $)$ and reduction cycles, respectively. To study the oxygen release/consumption behavior of the perovskites, several redox cycles including heating and cooling steps were carried out in a fluidized bed reactor with a length of $820 \mathrm{~mm}$ and a porous quartz plate of diameter $22 \mathrm{~mm}$ placed $370 \mathrm{~mm}$ from the bottom. For each experiment, the amount of sample was $15 \mathrm{~g}$. The reduction and oxidation cycles were initiated by changing the temperature between 600 and $1000{ }^{\circ} \mathrm{C}$ for each cycle. The system was flushed by air $\left(\mathrm{pO}_{2}: 0.21 \mathrm{~atm}\right)$ during the oxidation cycles and by $\mathrm{N}_{2}$ during the reduction cycles. The $\mathrm{O}_{2}$ level in the outlet gas was detected by a Rosemount NGA 2000 multicomponent gas analyzer.

\section{RESULTS}

To understand the redox characteristics of the doped calcium manganites used in this study, the properties of the pure calcium manganite were also investigated. The $\mathrm{CaMnO}_{3}$ system was chosen as it showed good performance as an oxygen carrier in a chemical looping oxygen uncoupling study. ${ }^{34}$ In the literature, thermochemical energy storage experiments are mainly carried out with either thermal analysis setups or packed bed reactors. ${ }^{6,35}$ In this study, the redox characteristics of the samples were investigated via both thermal analysis and fluidized bed experiments.

Figure $1 \mathrm{a}, \mathrm{b}$ shows the thermal behavior of CM under controlled atmosphere and the oxygen release/consumption

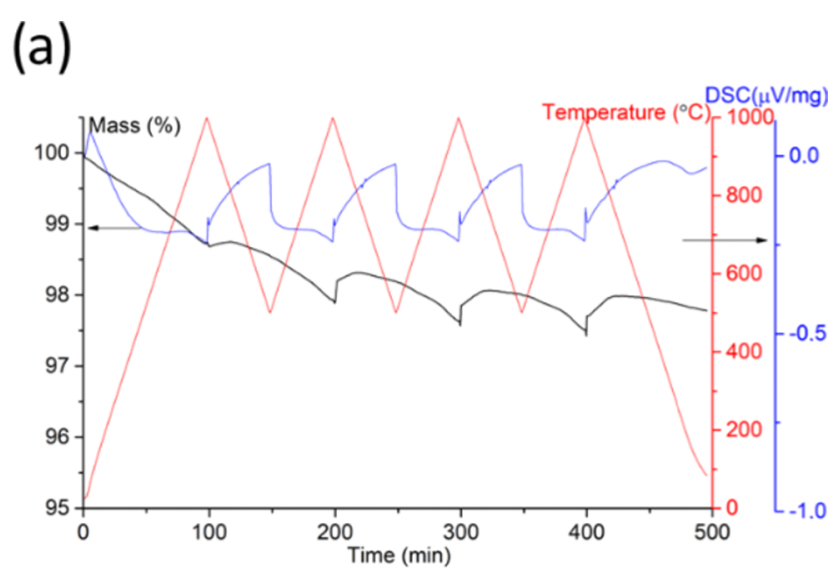

(b)

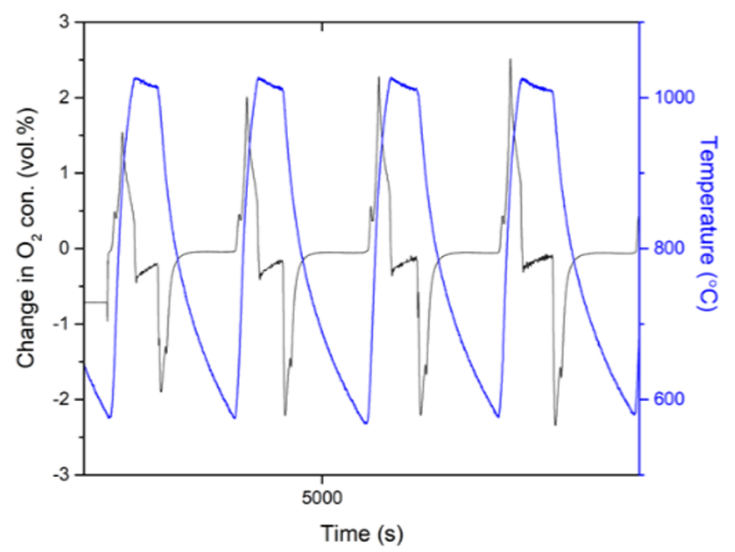

Figure 1. Thermal behavior of $\mathrm{CM}$ under controlled atmosphere (a) obtained by STA and $\mathrm{O}_{2}$ release/consumption ability of CM in the fluidized bed test (b). 
Table 2. Redox Properties of the Samples

\begin{tabular}{|c|c|c|c|c|c|c|c|c|c|c|}
\hline \multirow[b]{2}{*}{ sample } & \multicolumn{4}{|c|}{ thermal analysis } & \multicolumn{6}{|c|}{ fluidized bed experiments } \\
\hline & $T_{\text {peak,ox. }}\left({ }^{\circ} \mathrm{C}\right)$ & $\begin{array}{c}T_{\text {peak,red. }} \\
\left({ }^{\circ} \mathrm{C}\right)\end{array}$ & $\Delta w_{\text {,ox. }}(+$ & $\begin{array}{l}\Delta w_{\text {,red. }} \\
(-\%)\end{array}$ & $\begin{array}{l}T_{\text {peak,ox. }} \\
\left({ }^{\circ} \mathrm{C}\right)\end{array}$ & $T_{\text {peak,red. }}\left({ }^{\circ} \mathrm{C}\right)$ & $\Delta V \mathrm{O}_{2, \text { peak ox. }}^{\text {av. })}(+\%$, & $\begin{array}{c}\Delta V \mathrm{O}_{2, \text { peak red. }} \\
(-\%, \text { av. })\end{array}$ & $\begin{array}{l}\Delta m \mathrm{O}_{2, \text { ox. }}(+\mathrm{g}, \\
\text { av. })\end{array}$ & $\begin{array}{c}\Delta m \mathrm{O}_{2, \text { red. }}(-\mathrm{g}, \\
\text { av. }\end{array}$ \\
\hline $\mathrm{CM}$ & 795 & 970 & 0.2 & 0.4 & 885 & 970 & 2.20 & 2.22 & 0.23 & 0.31 \\
\hline CMF1 & 580 & 970 & 1.21 & 1.06 & 840 & 980 & 2.06 & 1.78 & 0.28 & 0.34 \\
\hline CMF2 & 610 & 975 & 1.06 & 1.02 & 830 & 980 & 1.69 & 1.64 & 0.24 & 0.32 \\
\hline CMM1 & 750 & 975 & 1.35 & 1.38 & 895 & 985 & 2.62 & 2.66 & 0.33 & 0.39 \\
\hline CMM2 & 770 & 980 & 1.32 & 1.37 & 885 & 980 & 2.08 & 2.05 & 0.29 & 0.37 \\
\hline $\mathrm{CMC1}$ & 730 & 975 & 0.75 & 1.15 & 870 & 945 & 2.11 & 2.33 & 0.29 & 0.35 \\
\hline $\mathrm{CMC} 2$ & 740 & 970 & 0.9 & 1.20 & 860 & 950 & 2.66 & 2.74 & 0.34 & 0.41 \\
\hline CMCF & 710 & 980 & 0.8 & 0.75 & 850 & 975 & 1.64 & 1.54 & 0.29 & 0.34 \\
\hline CMMT & 770 & 980 & 0.5 & 1.05 & 830 & 980 & 1.05 & 1.31 & 0.15 & 0.21 \\
\hline
\end{tabular}

behavior of $\mathrm{CM}$ in the fluidized bed test, respectively. The completion of a cycle involving heating and cooling takes 6000 $\mathrm{s}$ in STA, while it takes $1650 \mathrm{~s}$ in the fluidized bed test. These different time spans of applied thermocycles may affect the reaction kinetics, and different temperatures may be observed for redox cycles (Table 2). Possible reactions are given below (reactions 1-3). The expected mass loss for both reactions 1 and 2 is calculated as $5.6 \mathrm{wt} \%$ on average. The mass loss for reaction 3 may vary. Thermal analysis results showed that there was a mass loss of around $1.4 \mathrm{wt} \%$ within the first heating step, and the mass loss reached $2 \mathrm{wt} \%$ when the first cycle was completed. After the first cycle, the mass loss was around 0.4 wt $\%$ on average for each of the following cycles, while the mass gain was around $0.2 \mathrm{wt} \%$. The reduction onset $\left(T_{\text {red,on }}\right)$, where the reduction starts, and the peak temperature $\left(T_{\text {red,peak }}\right)$, where the reduction was observed as maximum, were recorded as 700 and $970{ }^{\circ} \mathrm{C}$, respectively. The oxidation onset temperature and the oxidation peak temperature were observed as 975 and $795{ }^{\circ} \mathrm{C}$, respectively. It was reported that $\delta$ for $\mathrm{CaMnO}_{3-\delta}$ is lower than 0.01 below $750{ }^{\circ} \mathrm{C}$ when the $\mathrm{pO}_{2}$ is above 0.01 in the system. ${ }^{36}$ In thermal analysis, $\mathrm{pO}_{2}$ was set to $0.21 \mathrm{~atm}$. From this point of view, most likely, only reactions 1 and 2 partly occurred simultaneously during the cycles in STA.

$$
\begin{aligned}
& 2 \mathrm{CaMnO}_{3} \rightarrow \mathrm{CaMn}_{2} \mathrm{O}_{4}+\mathrm{CaO}+\frac{1}{2} \mathrm{O}_{2(\mathrm{~g})} \\
& \mathrm{CaMnO}_{3} \rightarrow \frac{1}{2} \mathrm{Mn}_{2} \mathrm{O}_{3}+\mathrm{CaO}+\frac{1}{4} \mathrm{O}_{2(\mathrm{~g})} \\
& \mathrm{CaMnO}_{3} \rightarrow \mathrm{CaMnO}_{3-\delta}+\frac{\delta}{2} \mathrm{O}_{2(\mathrm{~g})}
\end{aligned}
$$

In the fluidized bed test, the result was slightly different. There was no significant temperature difference for reduction peaks between thermal analysis and fluidized bed test; however, the oxidation peak temperature observed in the fluidized bed test was around $90{ }^{\circ} \mathrm{C}$ higher than the thermal analysis. Since the heating and cooling rates in the fluidized bed are higher than those in the thermal analysis, different kinetic behavior may be expected for thermal analysis and fluidized bed test. ${ }^{37,38}$ The peak point of $\mathrm{O}_{2}$ release/consumption during the cycles was obtained from the gas analyzer data (Figure $1 \mathrm{~b}$ ). The total $\mathrm{O}_{2}$ release and consumption during the cycles were obtained via calculating the area under the oxidation and reduction peaks (Figure 1b). Two different phase transitions during both oxidation and reduction were reckoned to occur as there was a protrusion observed on the peaks. Theoretical $\mathrm{O}_{2}$ release and consumption during redox reaction via reaction 1 are calculated to be around 5.3 and $100 \mathrm{~g}$ of $\mathrm{CaMnO}_{3}$, respectively. Even though these values vary depending on $\delta$ for reaction 3, probably their averages will be lower than 1.12 and $100 \mathrm{~g}$ of $\mathrm{CaMnO}_{3}$, respectively. ${ }^{.636}$ Reactions 1 and 3 may be pathways for the redox reactions in the fluidized bed test, as average $\mathrm{O}_{2}$ consumption and release were detected around 0.23 and $0.31 \mathrm{~g}$ during oxidation and reduction, respectively. Most likely, the point where the protrusions were observed represents reaction 3, while the other peak was representative for where reaction 1 occurs. These formations were also revealed by XRD phase analysis after the fluidized bed tests (Figure S1), where $\mathrm{CaMnO}_{3-\delta}$ along with a low amount of $\mathrm{CaMn}_{2} \mathrm{O}_{4}$ were observed. Even though $\mathrm{CaMnO}_{3}$ has shown very promising performance for thermochemical energy storage applications in other studies, ${ }^{17,19,20,39}$ it did not show the best performance among the samples that were used in our study. This was already expected since the sample was already used as an oxygen carrier in a chemical looping oxygen uncoupling application, which may end up with decreased reactivity. The partial $\mathrm{O}_{2}$ pressure in this study was 0.21 bar, which is close to the real applications, where air is used without dilution. It is known that the amount of released oxygen would increase when the $\mathrm{pO}_{2}$ in the system decreases. ${ }^{18}$ As the other studies suggested that $\mathrm{CaMnO}_{3}$ may be reduced via reaction 3, where $\mathrm{pO}_{2}$ is lower than $0.18 \mathrm{~atm},{ }^{17,39}$ our study revealed that reaction 1 can also occur, where $\mathrm{pO}_{2}$ is above $0.21 \mathrm{~atm}$.

Promising results were obtained for both CLOU and TCES applications with $\mathrm{Fe}$ doping for $\mathrm{CaMnO}_{3} \cdot{ }^{18,30,39}$ It has been revealed that $\mathrm{Fe}$ doping enhances the reversible redox reactions of $\mathrm{CaMnO}_{3}$ and allows operation at higher temperatures than pure $\mathrm{CaMnO}_{3} .{ }^{39}$ In this study, we used two different $\mathrm{CaMn}_{1-x} \mathrm{Fe}_{x} \mathrm{O}_{3}(x=0.1$ and 0.2$)$, which have been used previously as an oxygen carrier in a CLOU application. The starting-phase compositions of $\mathrm{CaMn}_{0.9} \mathrm{Fe}_{0.1} \mathrm{O}_{3}$ and $\mathrm{CaMn}_{0.8} \mathrm{Fe}_{0.2} \mathrm{O}_{3}$ can be seen in Figures $\mathrm{S} 2$ and $\mathrm{S} 3$ in the Supporting Information, respectively. After the CLOU experiments, some $\mathrm{CaMn}_{2} \mathrm{O}_{4}$ formation was observed along with perovskite in both samples. In thermal analysis, the peak oxidation temperature was recorded as $580{ }^{\circ} \mathrm{C}$, which is 215 ${ }^{\circ} \mathrm{C}$ lower than pure $\mathrm{CaMnO}_{3}$ (Figure 2). A similar result was also observed in a related study, where the oxygen release onset temperature was lowered below $400{ }^{\circ} \mathrm{C}$ by Fe doping to $\mathrm{CaMnO}_{3} .{ }^{3939}$ Like $\mathrm{CaMn}_{0.9} \mathrm{Fe}_{0.1} \mathrm{O}_{3}, \mathrm{CaMn}_{0.8} \mathrm{Fe}_{0.2} \mathrm{O}_{3}$ also performed (Figure 3) a lower peak oxidation temperature $\left(610{ }^{\circ} \mathrm{C}\right)$ than pure $\mathrm{CaMnO}_{3}\left(795{ }^{\circ} \mathrm{C}\right)$. The reduction peak temperature was observed as 970 and $975{ }^{\circ} \mathrm{C}$ for $\mathrm{CaMn}_{0.9} \mathrm{Fe}_{0.1} \mathrm{O}_{3}$ and $\mathrm{CaMn}_{0.8} \mathrm{Fe}_{0.2} \mathrm{O}_{3}$, respectively. However, almost 6 times higher mass gain was observed for 
(a)

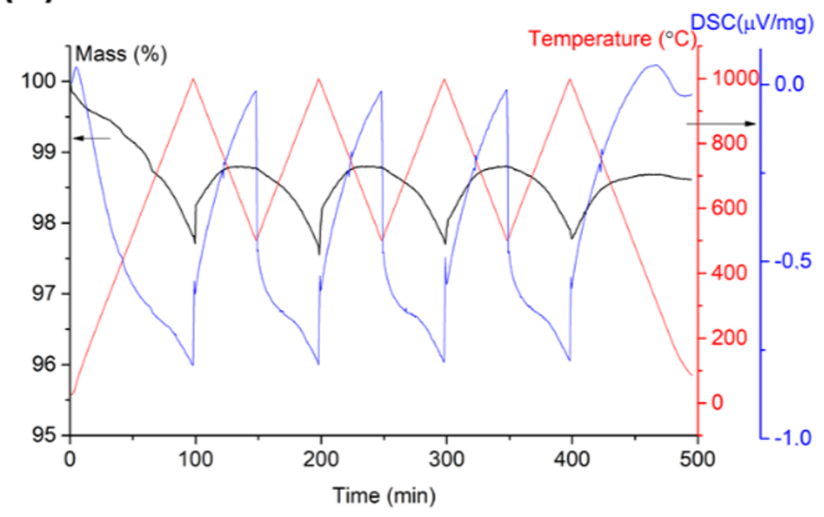

(b)

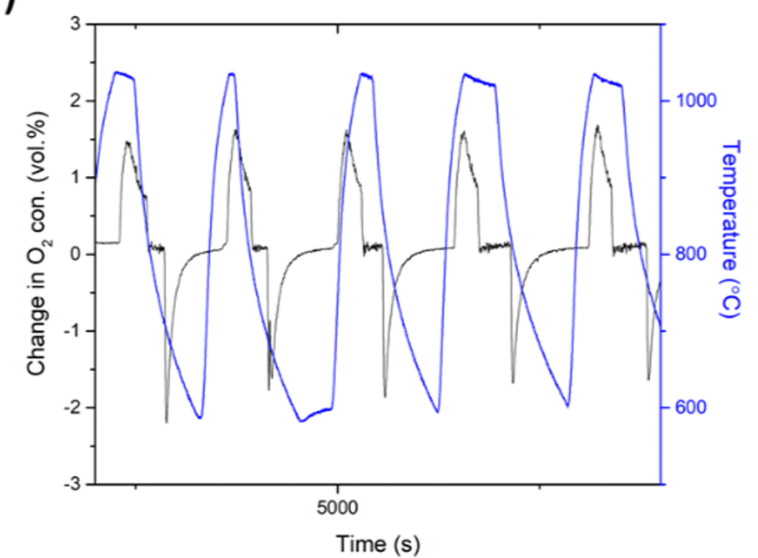

Figure 2. Thermal behavior of CMF1 under controlled atmosphere (a) obtained by STA and $\mathrm{O}_{2}$ release/consumption ability of CMF1 in the fluidized bed test $(\mathrm{b})$.

$\mathrm{CaMn}_{0.9} \mathrm{Fe}_{0.1} \mathrm{O}_{3}$ and the mass loss was 2.65-fold higher than $\mathrm{CaMnO}_{3}$ during oxidation and reduction, respectively. The mass gain/loss was recorded as $1.06 \mathrm{wt} \%$ during oxidation and 1.02 wt \% during reduction.

Fe-doped $\mathrm{CaMnO}_{3}$ samples showed higher redox peak temperatures in fluidized bed experiments than in thermal analysis. This result was not surprising considering the slow reduction kinetics of $\mathrm{Fe}$ oxides. In addition, $\mathrm{pO}_{2}$ was set to $0.21 \mathrm{bar}$ in the fluidized bed, which makes the reduction more difficult compared to lower $\mathrm{pO}_{2}$ values since $\mathrm{Fe}$ oxides do not have oxygen release ability under these conditions. The oxidation peak temperature was recorded as 840 and $830{ }^{\circ} \mathrm{C}$ for $\mathrm{CaMn}_{0.9} \mathrm{Fe}_{0.1} \mathrm{O}_{3}$ and $\mathrm{CaMn}_{0.8} \mathrm{Fe}_{0.2} \mathrm{O}_{3}$, respectively, while the reduction peak temperature was $980{ }^{\circ} \mathrm{C}$ for both. In fluidized bed tests, $\mathrm{CaMn}_{0.9} \mathrm{Fe}_{0.1} \mathrm{O}_{3}$ showed better performance than $\mathrm{CaMn}_{0.8} \mathrm{Fe}_{0.2} \mathrm{O}_{3}$ with regard to the amount of $\mathrm{O}_{2}$ released/ consumed. Therefore, $\mathrm{Fe}$-doped calcium manganese oxides can be easily put forward to enhance the redox properties of $\mathrm{CaMnO}_{3}$ systems.

It is known that B-site dopant will have a higher impact than the A-site dopant on vacancy creation, which is related to the oxygen release ability of the compound. ${ }^{36}$ However, the effect of $\mathrm{MgO}$ addition to the $\mathrm{B}$ site was tested for a CLOU application. ${ }^{32,40}$ A study revealed that $\mathrm{MgO}$-doped $\mathrm{CaMnO}_{3}$ showed good stability in a 50-cycle test and a small increase in reactivity was also observed. ${ }^{32}$ Both in thermal analysis and fluidized bed experiments (Figures 4 and 5 for CMM1 and (a)

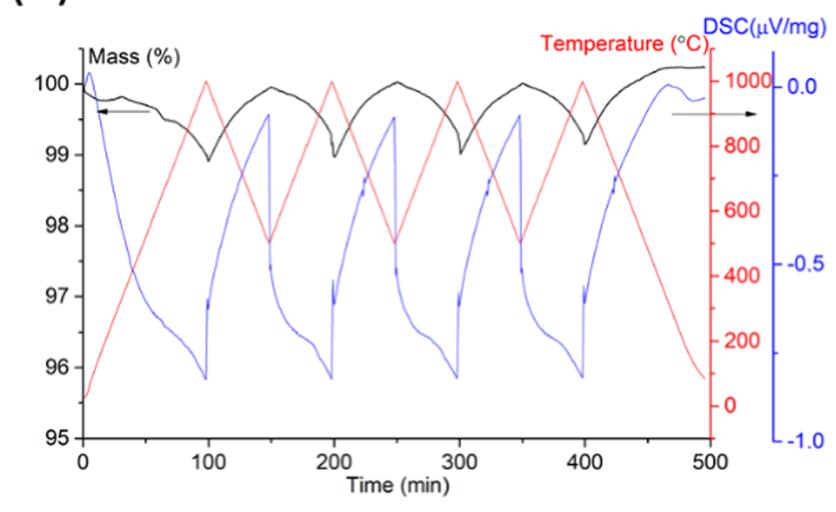

(b)

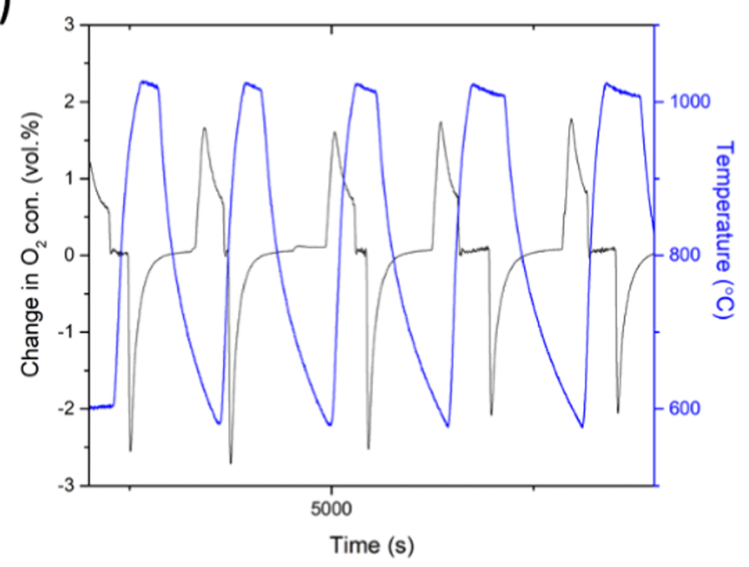

Figure 3. Thermal behavior of CMF2 under controlled atmosphere (a) obtained by STA and $\mathrm{O}_{2}$ release/consumption ability of CMF2 in the fluidized bed test (b).

CMM2, respectively), the reduction peak temperature was observed around $975-985{ }^{\circ} \mathrm{C}$ for both $\mathrm{MgO}$-doped $\mathrm{CaMnO}_{3}$. However, the oxidation peak temperature was obtained as 750 ${ }^{\circ} \mathrm{C}$ in thermal analysis, while it was $895{ }^{\circ} \mathrm{C}$ in fluidized bed test for $\mathrm{CaMn}_{0.9} \mathrm{Mg}_{0.1} \mathrm{O}_{3}$. This difference most likely occurred due to the slow reoxidation kinetics of the $\mathrm{CaMnO}_{3}$, like the other doped $\mathrm{CaMnO}_{3}$ samples. This temperature difference between the experiments was also observed for $\mathrm{CaMn}_{0.8} \mathrm{Mg}_{0.2} \mathrm{O}_{3}$, as expected. The phase analysis of the fresh and used samples of CMM1 and CMM2 revealed that there was free $\mathrm{MgO}$ in the system along with the perovskite structure (Figures S4 and S5). Most likely, a part of the perovskite dissociated into $\mathrm{MgO}$ and $\mathrm{Ca}_{2} \mathrm{MnO}_{4}$ during a previous CLOU application. There was no free $\mathrm{MgO}$ in the starting sample before it had been used in a CLOU application. However, as the intensity ratio of the $\mathrm{MgO}$ was different in the fresh sample (after CLOU) than in the used sample (after fluidized bed tests), $\mathrm{MgO}$ dissociation was thought to have occurred during the experiments. Even though there was only a $25-45{ }^{\circ} \mathrm{C}$ temperature difference for the oxidation peak temperature of $\mathrm{MgO}$-doped $\mathrm{CaMnO}_{3}$ samples and pure $\mathrm{CaMnO}_{3}$ in the thermal analysis, the mass gain was 6.75 times higher for $\mathrm{CaMn}_{0.9} \mathrm{Mg}_{0.1} \mathrm{O}_{3}$ and 5 times higher for $\mathrm{CaMn}_{0.8} \mathrm{Mg}_{0.2} \mathrm{O}_{3}$ than for pure $\mathrm{CaMnO}_{3}$. A similar result was obtained in the fluidized bed tests as well. The average oxygen peak release was recorded as 2.66 vol \% for $\mathrm{CaMn}_{0.9} \mathrm{Mg}_{0.1} \mathrm{O}_{3}$ for reduction steps. The peak oxygen consumption was recorded around 2.62 vol \% for oxidation steps. Among the $\mathrm{MgO}$-doped samples, the best results were obtained with 
(a)

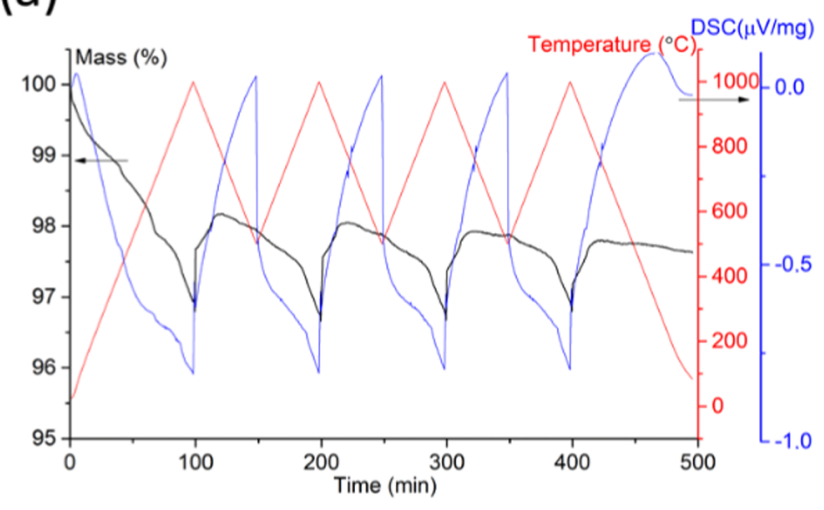

(b)

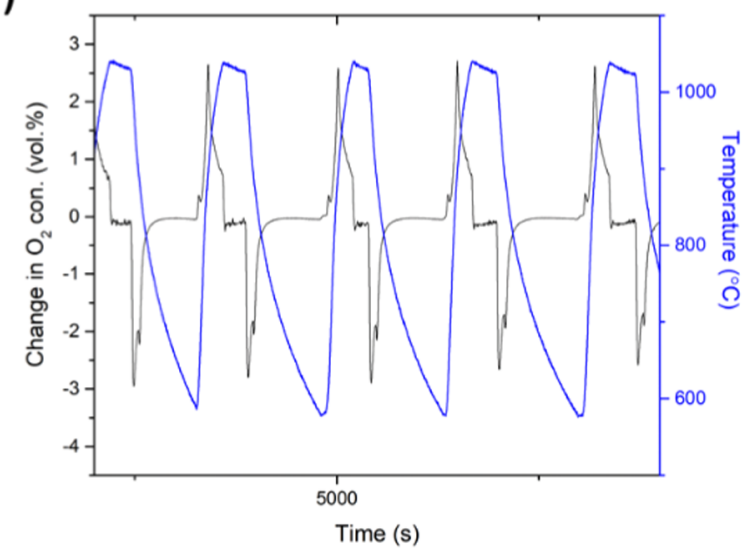

Figure 4. Thermal behavior of CMM1 under controlled atmosphere (a) obtained by STA and $\mathrm{O}_{2}$ release/consumption ability of CMM1 in the fluidized bed test (b).

$\mathrm{CaMn}_{0.9} \mathrm{Mg}_{0.1} \mathrm{O}_{3}$. The different redox characteristics of the $\mathrm{MgO}$-doped $\mathrm{CaMnO}_{3}$ samples and the pure $\mathrm{CaMnO}_{3}$ supported that $\mathrm{MgO}$ was still present in the perovskite system despite the observed phase dissociation.

$\mathrm{Cu}$ is one of the most well-known materials both for both chemical looping oxygen uncoupling and thermochemical energy storage applications. ${ }^{14,41,42}$ However, a support material to combine with $\mathrm{CuO}$ is generally proposed due to the low melting point and the relatively high cost of the pure copper compounds. ${ }^{43}$ From this point of view, $\mathrm{CuO}$-doped $\mathrm{CaMnO}_{3}$ samples were also tested in this study. The phase analyses of CMC1 and CMC2 are presented in Figures S6 and S7, respectively. In Figure 6, the simultaneous thermal analysis and fluidized bed test results were given for $\mathrm{CaMn}_{0.9} \mathrm{Cu}_{0.1} \mathrm{O}_{3}$. The reduction peak temperature was obtained as 975 and $945^{\circ} \mathrm{C}$ in the thermal analysis and the fluidized bed test, respectively. There was only a $25{ }^{\circ} \mathrm{C}$ difference observed between pure $\mathrm{CaMnO}_{3}$ and $\mathrm{CaMn}_{0.9} \mathrm{Cu}_{0.1} \mathrm{O}_{3}$ for the reduction peak temperature in the fluidized bed test. This difference most likely occurred due to the $\mathrm{CuO}$ addition. This hypothesis was also supported by the results of $\mathrm{CaMn}_{0.2} \mathrm{Cu}_{0.2} \mathrm{O}_{3}$ (Figure 7). The difference for the reduction peak temperature was obtained to be around $20{ }^{\circ} \mathrm{C}$ between pure $\mathrm{CaMnO}_{3}$ and $\mathrm{CaMn}_{0.8} \mathrm{Cu}_{0.2} \mathrm{O}_{3}$. The oxidation peak temperatures were observed to 730 and $740{ }^{\circ} \mathrm{C}$, while it was found to be $795{ }^{\circ} \mathrm{C}$ for pure $\mathrm{CaMnO}_{3}$. The difference for the recorded oxidation peak temperature was smaller in the fluidized bed tests between $\mathrm{CuO}$-doped $\mathrm{CaMnO}_{3}\left(870\right.$ and $860{ }^{\circ} \mathrm{C}$, respectively) and pure $\mathrm{CaMnO}_{3}$. (a)

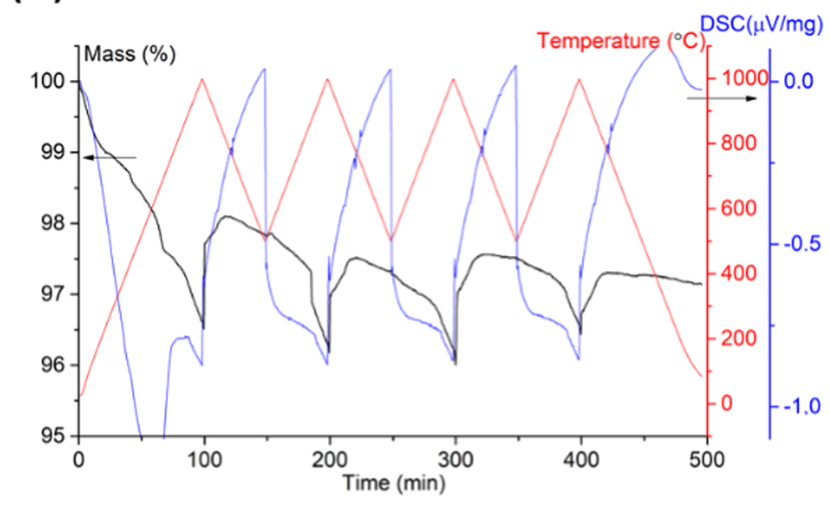

(b)

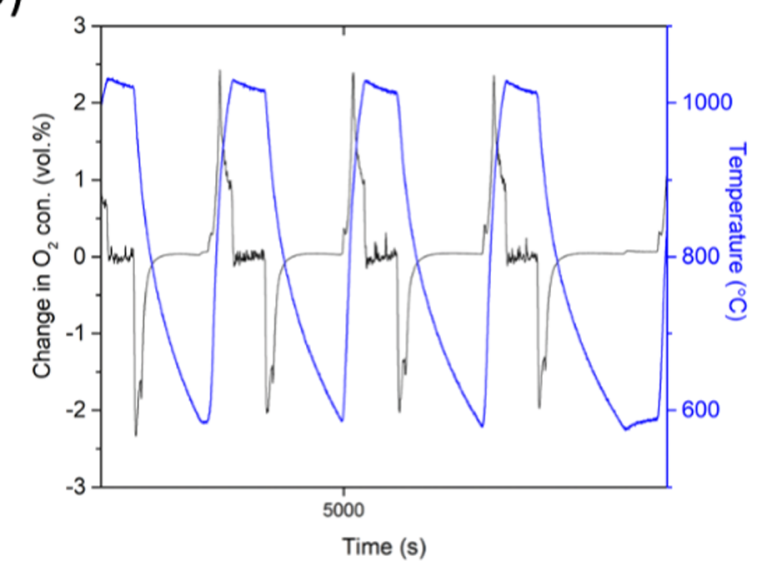

Figure 5. Thermal behavior of CMM2 under controlled atmosphere (a) obtained by STA and $\mathrm{O}_{2}$ release/consumption ability of CMM2 in the fluidized bed test (b).

Copper affected the mass gain/mass loss positively in the thermal analysis. During the oxidation cycles, 0.75 wt $\%$ mass gain was observed for $\mathrm{CaMn}_{0.9} \mathrm{Cu}_{0.1} \mathrm{O}_{3}$. For $\mathrm{CaMn}_{0.2} \mathrm{Cu}_{0.2} \mathrm{O}_{3}$, it was even higher and recorded as 0.9 wt \%. During the reduction cycles, the mass loss was obtained as 1.15 and $1.2 \mathrm{wt}$ $\%$ for $\mathrm{CaMn}_{0.9} \mathrm{Cu}_{0.1} \mathrm{O}_{3}$ and $\mathrm{CaMn}_{0.2} \mathrm{Cu}_{0.2} \mathrm{O}_{3}$, respectively. Fluidized bed tests also showed a similar result to thermal analysis. During the oxidation cycles, average $\mathrm{O}_{2}$ consumption by $\mathrm{CaMn}_{0.9} \mathrm{Cu}_{0.1} \mathrm{O}_{3}$ and $\mathrm{CaMn}_{0.2} \mathrm{Cu}_{0.2} \mathrm{O}_{3}$ was 0.29 and $0.34 \mathrm{~g}$, respectively. During the reduction cycles, $0.35 \mathrm{~g}$ of $\mathrm{O}_{2}$ was released by $\mathrm{CaMn}_{0.9} \mathrm{Cu}_{0.1} \mathrm{O}_{3}$ and the value was $0.41 \mathrm{~g}$ for $\mathrm{CaMn}_{0.2} \mathrm{Cu}_{0.2} \mathrm{O}_{3}$. Among the tested samples, $\mathrm{Cu}$-doped $\mathrm{CaMnO}_{3}$ showed one of the best performances together with $\mathrm{Mg}$-doped $\mathrm{CaMnO}_{3}$.

The combined transitional-metal doping to $\mathrm{CaMnO}_{3}$ has also been studied. ${ }^{29,30}$ As both $\mathrm{Fe}$ and $\mathrm{Cu}$ dopings show better performance than pure $\mathrm{CaMnO}_{3}$, the effect of the combined doping of $\mathrm{Cu}$ and $\mathrm{Fe}$ was tested as well (Figure 8). In addition, a well-studied oxygen carrier $\mathrm{CMMT}^{26,32,33}$ was also tested after being used in a CLOU application. Despite the individual high performance of $\mathrm{Cu}$ - and $\mathrm{Fe}$-doped $\mathrm{CaMnO}_{3}$ samples, $\mathrm{Cu}$ and $\mathrm{Fe}$-doped $\mathrm{CaMnO}_{3}$ could not show the same performance in the thermal analysis tests. This most likely occurred due to the phase dissociation after the CLOU operation (Figure S8). However, as the dissociated compounds may also exhibit redox behavior, the performance of the material was still promising. The peak reduction temperature obtained from the thermal 
(a)

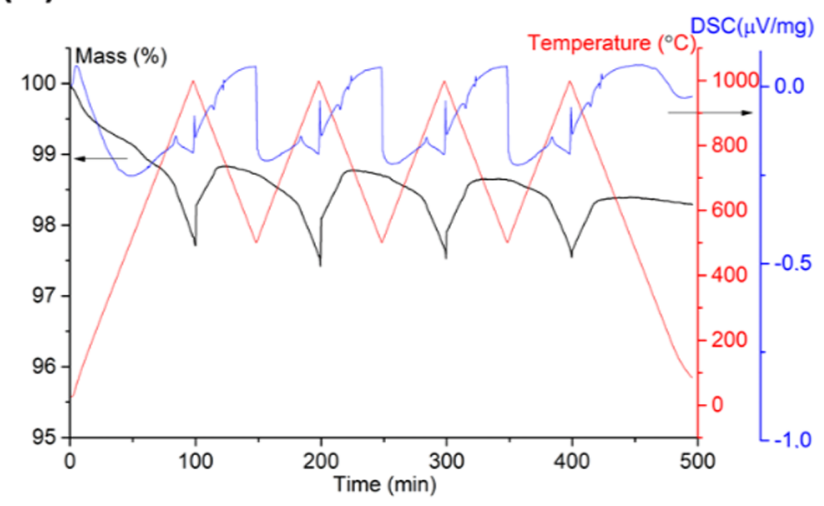

(b)

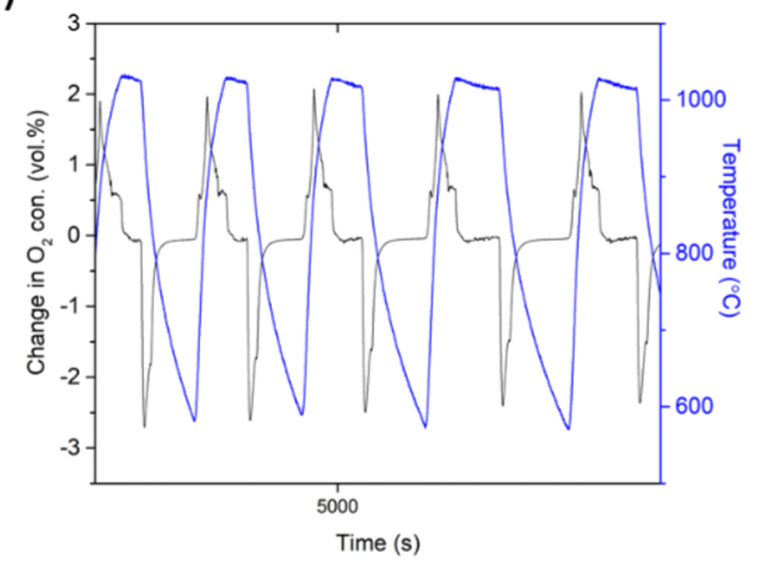

Figure 6. Thermal behavior of CMC1 under controlled atmosphere (a) obtained by STA and $\mathrm{O}_{2}$ release/consumption ability of CMC1 in the fluidized bed test (b).

analysis was similar $\left(980{ }^{\circ} \mathrm{C}\right)$ to CMF and CMC (970-975 ${ }^{\circ} \mathrm{C}$ ). However, the oxidation peak temperature of $\mathrm{CMCF}$ was recorded as $710^{\circ} \mathrm{C}$, which was similar to that of the CMC samples $\left(730-740^{\circ} \mathrm{C}\right)$ but quite higher than that of the CMF samples $\left(580-610^{\circ} \mathrm{C}\right)$. The mass gain during oxidation and the mass loss during the reduction were recorded as 0.8 and 0.75 wt \%, respectively. Even though CMCF did not exhibit the best performance, it was more stable than other samples in a manner of cyclic mass change. For the fluidized bed tests, there was no significant temperature difference observed between the $\mathrm{CMCF}, \mathrm{CMF}$, and $\mathrm{CMC}$. However, $\mathrm{CMCF}$ also showed a way better performance than pure $\mathrm{CM}$ sample. CMC, CMF, and CMCF consumed and released similar amounts of $\mathrm{O}_{2}$ during the redox cycles in the fluidized bed tests. However, CMCF exhibited slower kinetics, which can be explained by the wider and shorter $\mathrm{O}_{2}$ consumption/releasing peaks than CMC and CMF samples.

CMMT was mentioned in the literature as a stable and highperformance oxygen carrier for CLOU. ${ }^{26,32,33}$ However, CMMT could not show a high TES performance in this study. There was no significant temperature difference between CMMT, CMM, and CM for the redox peak temperatures when comparing the thermal analysis and the fluidized bed tests (Figure 9). The mass loss/gain performance of CMMT was almost $40 \%$ lower than that of CMM samples in the thermal analysis. However, CMMT showed 2.5 times higher mass gain/loss than CM. The fluidized bed test performance of (a)

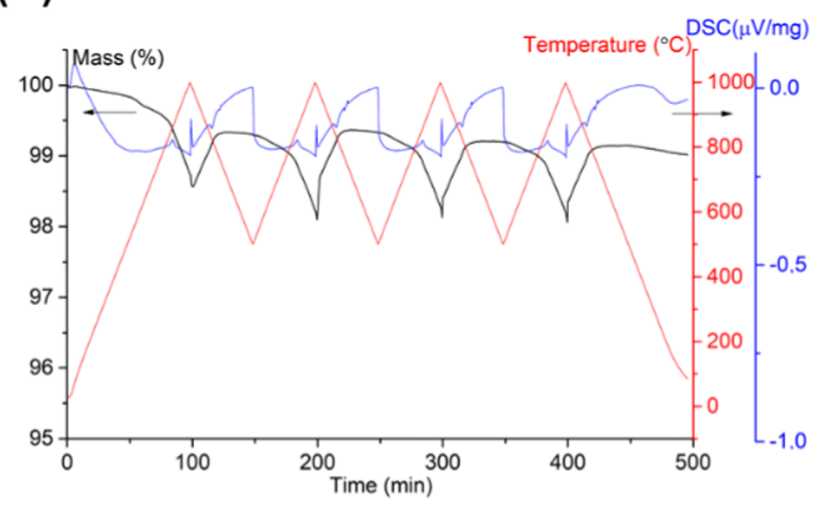

(b)

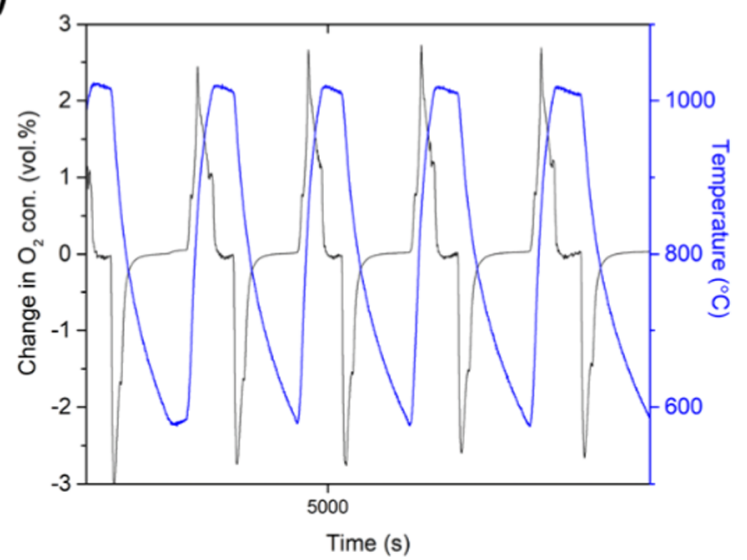

Figure 7. Thermal behavior of CMC2 under controlled atmosphere (a) obtained by STA and $\mathrm{O}_{2}$ release/consumption ability of CMC2 in the fluidized bed test (b).

CMMT was slightly different from that of the thermal analysis. In the fluidized bed tests, CMMT exhibited even lower $\mathrm{O}_{2}$ uptake/release performance than CM. The decrease in the performance most likely occurred due to a new phase formation, $\mathrm{Ti}_{0.9} \mathrm{Mg}_{0.1} \mathrm{O}_{5}$, which was detected via phase analysis (Figure S9).

\section{DISCUSSION}

Thermochemical energy storage (TCES) applications are crucial to store energy in a clean way and to conserve the primary energy sources. ${ }^{44}$ Therefore, it offers an opportunity to help reduce greenhouse gas emissions. ${ }^{44}$ Carbon capture and storage (CCS) technologies are also important to tackle climate change. ${ }^{45}$ Recently, materials can be used in both thermochemical energy storage applications and carbon capture and storage applications. ${ }^{46}$ For both applications, the candidate materials should be cost-effective, environmentally friendly, and thermochemically stable. ${ }^{47,48}$ Since a high amount of materials are needed in industrial applications for both methods, it would be valuable to recycle the "used" materials by another application or to use a low-cost material such as waste or ore. From this point of view, promising doped $\mathrm{CaMnO}_{3}$-based oxygen carriers used in chemical looping oxygen uncoupling (CLOU) applications were tested for potential TCES. Calcium manganite-based samples were designed to have a certain composition, which is given in Table 1 when they were synthesized for CLOU applica- 
(a)

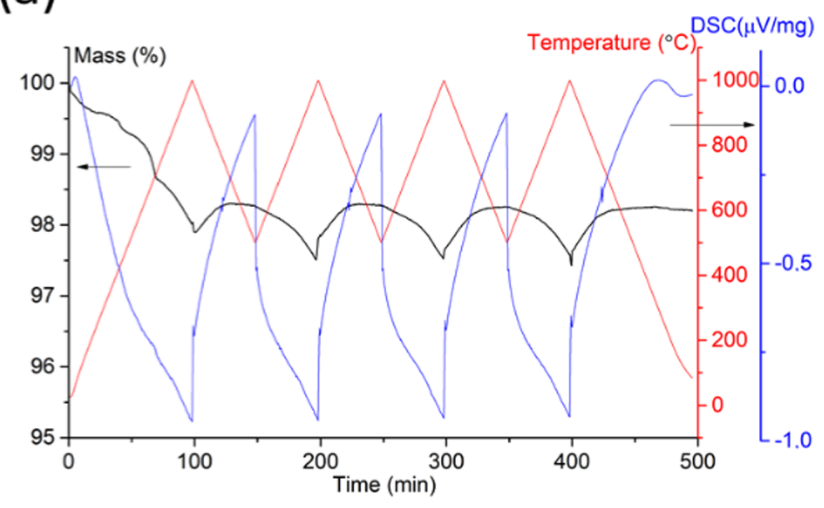

(b)

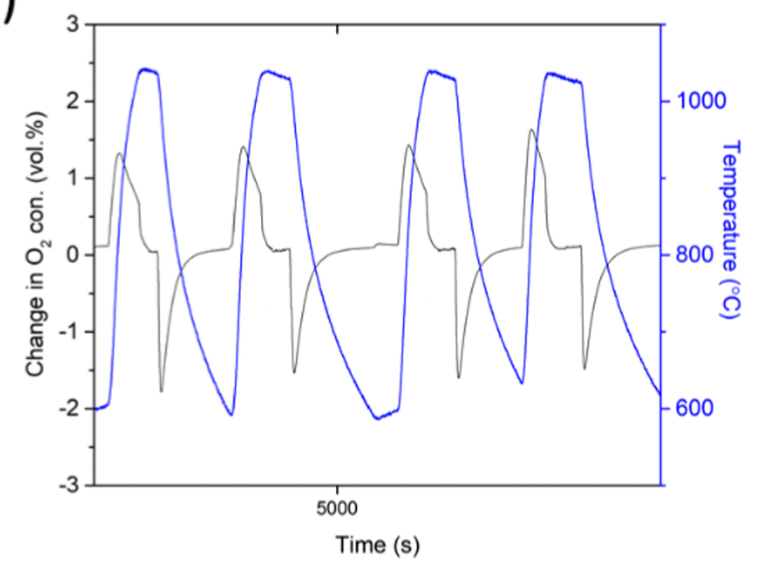

Figure 8. Thermal behavior of CMCF under controlled atmosphere (a) obtained by STA and $\mathrm{O}_{2}$ release/consumption ability of CMCF in the fluidized bed test $(\mathrm{b})$.

tions. $^{26,29-33}$ A fresh material that is not used in any CLOU operation would most likely exhibit a higher performance than that obtained in this study, since perovskite-based materials are well known as good candidates for thermochemical energy storage applications. ${ }^{49}$ Even though fresh materials were beyond the scope of this study, phase analysis was carried out on both fresh samples and used samples in a CLOU application to reveal the effect of the CLOU operation on the phase structure of the samples. However, no difference was observed regarding phase structure, which was also observed in other related studies. ${ }^{29,31}$ Although the metal oxide-based CLOU and TCES applications are similar in the oxidation manner, CLOU has a harsher reduction step, where a fuel is used as the reduction tool. Therefore, we have tested the used material in a CLOU application to mimic the worst-case scenario in a manner of thermochemical stability.

Fluidized bed experiments were used to investigate the oxygen release/consumption behavior of the samples related to temperature changes, whereas thermal analysis combined with differential scanning calorimetry could reveal the possible phase transitions without weight loss/gain in the system. It is important to use a sufficiently large amount of sample in the tests to mimic the real applications. However, the amount of sample used is very limited in the thermal analysis experiments for practical reasons. But thermal analysis results are important to reveal thermodynamic characteristics and to mimic the ideal conditions, where the heating and cooling rates are predefined and strictly controlled. From this point of view, simultaneous (a)

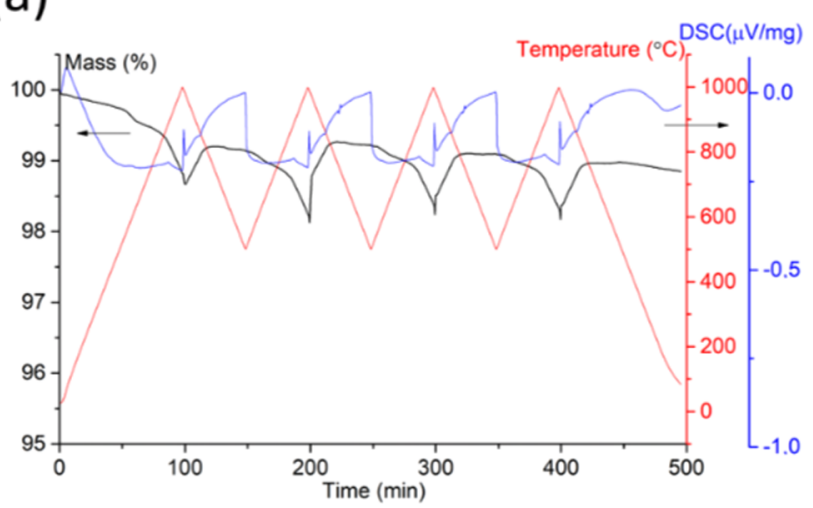

(b)

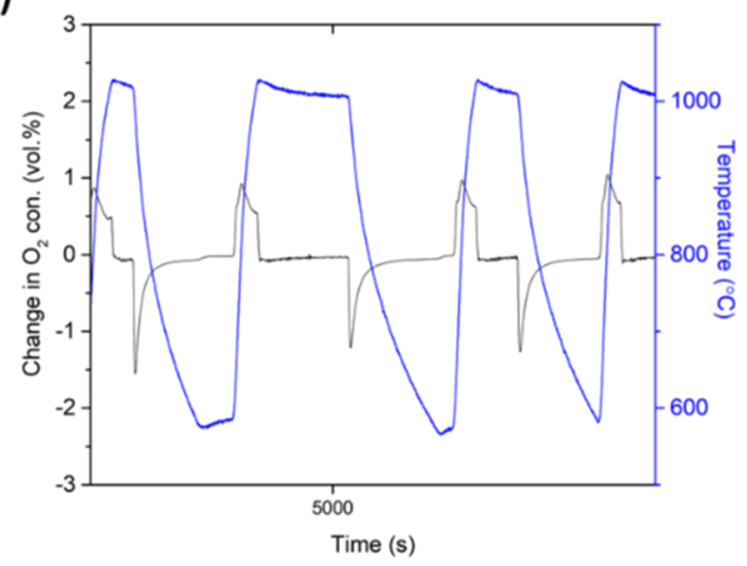

Figure 9. Thermal behavior of CMMT under controlled atmosphere (a) obtained by STA and $\mathrm{O}_{2}$ release/consumption ability of CMMT in the fluidized bed test (b).

thermal analysis and fluidized bed tests were used as complementary techniques in this study.

Decomposition of the particles into a smaller size can be observed in a reduction step, and an oxidation step may cause some agglomeration due to the sintering effect in CLOU applications. ${ }^{50}$ Therefore, before testing the particles in fluidized bed experiments or in thermal analysis, the samples were sieved into the $180-250 \mu \mathrm{m}$ size range to ensure that all particles have the same size range without any fragmented particles. After the fluidized bed experiments, all samples were investigated under a scanning electron microscope and secondary electron images were recorded to investigate the thermomechanical and morphological stabilities of the particles (Figure S10). It is worth noting that the number of redox cycles applied should be increased to have better understanding of the thermomechanical stability of the oxygen carriers. However, the poorest thermomechanical stability after the applied cycles was observed on Fe-doped $\mathrm{CaMnO}_{3}$ samples, while the $\mathrm{Cu}$ - and Fe-doped $\mathrm{CaMnO}_{3}$ samples showed the highest thermomechanical stability.

Among the samples, the highest $\mathrm{O}_{2}$ release/consumption in the fluidized bed tests was obtained with the $\mathrm{CaMn}_{0.8} \mathrm{Cu}_{0.2} \mathrm{O}_{3}$ sample. For thermal analysis experiment, $\mathrm{CaMn}_{0.9} \mathrm{Mg}_{0.1} \mathrm{O}_{3}$ showed the best performance for the highest mass change. From DSC curves, the heat storage capacities were calculated for the samples that showed the best performance. The heat storage capacity was calculated as $280 \mathrm{~kJ} / \mathrm{kg}$ for 
$\mathrm{CaMn}_{0.9} \mathrm{Mg}_{0.1} \mathrm{O}_{3}$ and $430 \mathrm{~kJ} / \mathrm{kg}$ for $\mathrm{CaMn}_{0.8} \mathrm{Cu}_{0.2} \mathrm{O}_{3}$. The heat storage capacity of pure $\mathrm{CaMnO}_{3}$ was also calculated $(240 \mathrm{~kJ} /$ $\mathrm{kg}$ ) to reveal the difference of CM, CMM1, and CMC2. The obtained heat storage capacity of pure CM was slightly lower than the reported values in the literature. ${ }^{39}$ Most likely, this difference occurred due to the formation of $\mathrm{CaMn}_{2} \mathrm{O}_{4}$ in the pure CM sample after the CLOU operation.

\section{CONCLUSIONS}

In this work, calcium manganite-based oxides used in chemical looping oxygen uncoupling (CLOU) applications were tested as a potential thermochemical energy storage material. The dopant effects of $\mathrm{Fe}_{2} \mathrm{O}_{3}, \mathrm{MgO}, \mathrm{CuO}, \mathrm{Fe}_{2} \mathrm{O}_{3} \& \mathrm{CuO}$, and ${\mathrm{MgO} \& \mathrm{TiO}_{2}}_{2}$ were also investigated to compare their performance with pure $\mathrm{CaMnO}_{3}$. Even though materials may end up with decreased reactivity after being used in CLOU applications, the results showed that promising calcium manganites for CLOU applications showed good performance also for thermochemical energy storage applications. The highest $\mathrm{O}_{2}$ release/reoxidation performance among the tested samples was exhibited by $\mathrm{CaMn}_{0.8} \mathrm{Cu}_{0.2} \mathrm{O}_{3}$, and the heat storage capacity was calculated as $430 \mathrm{~kJ} / \mathrm{kg} \mathrm{CaMn}{ }_{0.8} \mathrm{Cu}_{0.2} \mathrm{O}_{3}$. However, $\mathrm{CaMn}_{0.9} \mathrm{Mg}_{0.1} \mathrm{O}_{3}$ showed the best cyclic stability, which is also important for materials' lifetime. This study showed that the utilization of recycled CLOU materials in a thermochemical energy storage application may be possible if a chosen oxygen carrier shows high cyclic stability.

\section{ASSOCIATED CONTENT}

\section{SI Supporting Information}

The Supporting Information is available free of charge at https://pubs.acs.org/doi/10.1021/acs.iecr.0c05182.

Detailed characterization of the samples (PDF)

\section{AUTHOR INFORMATION}

\section{Corresponding Author}

Duygu Yilmaz - Chemistry and Chemical Engineering, Chalmers University of Technology, 41258 Gothenburg, Sweden; (1) orcid.org/0000-0002-4142-4788;

Email: duyguy@chalmers.se

\section{Authors}

Esraa Darwish - Chemistry and Chemical Engineering, Chalmers University of Technology, 41258 Gothenburg, Sweden

Henrik Leion - Chemistry and Chemical Engineering, Chalmers University of Technology, 41258 Gothenburg, Sweden; (1) orcid.org/0000-0002-9716-2553

Complete contact information is available at:

https://pubs.acs.org/10.1021/acs.iecr.0c05182

\section{Notes}

The authors declare no competing financial interest.

\section{ACKNOWLEDGMENTS}

This project was funded by Adlerbertska Foundation (21285157) and Iris Stipendiet (IR2020-0195).

\section{REFERENCES}

(1) Ervin, G. Solar Heat Storage Using Chemical Reactions. J. Solid State Chem. 1977, 22, 51-61.
(2) Wentworth, W. E.; Chen, E. Simple Thermal Decomposition Reactions for Storage of Solar Thermal Energy. Sol. Energy 1976, 18, 205-214.

(3) André, L.; Abanades, S.; Flamant, G. Screening of Thermochemical Systems Based on Solid-Gas Reversible Reactions for High Temperature Solar Thermal Energy Storage. Renewable Sustainable Energy Rev. 2016, 64, 703-715.

(4) André, L.; Abanades, S.; Cassayre, L. Experimental Investigation of $\mathrm{Co}-\mathrm{Cu}, \mathrm{Mn}-\mathrm{Co}$, and $\mathrm{Mn}-\mathrm{Cu}$ Redox Materials Applied to Solar Thermochemical Energy Storage. ACS Appl. Energy Mater. 2018, 1, 3385-3395.

(5) Michel, B.; Mazet, N.; Mauran, S.; Stitou, D.; Xu, J. Thermochemical Process for Seasonal Storage of Solar Energy: Characterization and Modeling of a High Density Reactive Bed. Energy. Energy 2012, 47, 553-563.

(6) Pardo, P.; Deydier, A.; Anxionnaz-Minvielle, Z.; Rougé, S.; Cabassud, M.; Cognet, P. A Review on High Temperature Thermochemical Heat Energy Storage. Renewable Sustainable Energy Rev. 2014, 32, 591-610.

(7) Block, T.; Schmücker, M. Metal Oxides for Thermochemical Energy Storage: A Comparison of Several Metal Oxide Systems. Sol. Energy 2016, 126, 195-207.

(8) Carrillo, A. J.; Serrano, D. P.; Pizarro, P.; Coronado, J. M. Thermochemical Heat Storage Based on the Mn2O3/Mn3O4 Redox Couple: Influence of the Initial Particle Size on the Morphological Evolution and Cyclability. J. Mater. Chem. A 2014, 2, 19435-19443.

(9) Carrillo, A. J.; Serrano, D. P.; Pizarro, P.; Coronado, J. M. Improving the Thermochemical Energy Storage Performance of the $\mathrm{Mn} 2 \mathrm{O} 3 / \mathrm{Mn} 3 \mathrm{O} 4 \mathrm{redox}$ Couple by the Incorporation of Iron. ChemSusChem 2015, 8, 1947-1954.

(10) Wokon, M.; Bauer, T.; Linder, M. Investigations on Thermochemical Energy Storage Based on Manganese-Iron Oxide in a Lab-Scale Reactor. AIP Conf. Proc. 2017, 1850, No. 090008.

(11) Carrillo, A. J.; Moya, J.; Bayón, A.; Jana, P.; De La Peña O’Shea, V. A.; Romero, M.; Gonzalez-Aguilar, J.; Serrano, D. P.; Pizarro, P.; Coronado, J. M. Thermochemical Energy Storage at High Temperature via Redox Cycles of $\mathrm{Mn}$ and Co Oxides: Pure Oxides versus Mixed Ones. Sol. Energy Mater. Sol. Cells 2014, 123, 47-57.

(12) Carrillo, A. J.; Serrano, D. P.; Pizarro, P.; Coronado, J. M. Manganese Oxide-Based Thermochemical Energy Storage: Modulating Temperatures of Redox Cycles by $\mathrm{Fe}-\mathrm{Cu} \mathrm{Co}$-Doping. J. Energy Storage 2016, 5, 169-176.

(13) André, L.; Abanades, S.; Cassayre, L. Experimental and Thermodynamic Study of Co-Fe and Mn-Fe Based Mixed Metal Oxides for Thermochemical Energy Storage Application. AIP Conf. Proc. 2017, 1850, No. 090002.

(14) André, L.; Abanades, S.; Cassayre, L. Mixed Metal Oxide Systems Applied to Thermochemical Storage of Solar Energy: Benefits of Secondary Metal Addition in Co and Mn Oxides and Contribution of Thermodynamics. Appl. Sci. 2018, 8, No. 2618.

(15) Carrillo, A. J.; Serrano, D. P.; Pizarro, P.; Coronado, J. M. Thermochemical Heat Storage at High Temperatures Using Mn2O3/ Mn3O4 System: Narrowing the Redox Hysteresis by Metal CoDoping. Energy Procedia 2015, 73, 263-271.

(16) Block, T.; Schmücker, M. Metal Oxides for Thermochemical Energy Storage: A Comparison of Several Metal Oxide Systems. Sol. Energy 2016, 126, 195-207.

(17) Bulfin, B.; Vieten, J.; Starr, D. E.; Azarpira, A.; Zachäus, C.; Hävecker, M.; Skorupska, K.; Schmücker, M.; Roeb, M.; Sattler, C. Redox Chemistry of $\mathrm{CaMnO} 3$ and $\mathrm{Ca} 0.8 \mathrm{Sr} 0.2 \mathrm{MnO} 3$ Oxygen Storage Perovskites. J. Mater. Chem. A 2017, 5, 7912-7919.

(18) Imponenti, L.; Albrecht, K. J.; Kharait, R.; Sanders, M. D.; Jackson, G. S. Redox Cycles with Doped Calcium Manganites for Thermochemical Energy Storage to $1000^{\circ} \mathrm{C}$. Appl. Energy 2018, 230, $1-18$.

(19) Rørmark, L.; Mørch, A. B.; Wiik, K.; Stølen, S.; Grande, T. Enthalpies of Oxidation of CaMnO3- $\delta$, Ca2MnO4- $\delta$ and $\mathrm{SrMnO} 3-\delta$ Deduced Redox Properties. Chem. Mater. 2001, 13, 4005-4013. 
(20) Yu, N.; Nair, M. M.; Mahinpey, N. Structure and Phase Evolution of CaMnO3 Perovskite during Isothermal Redox Cycles. Can. J. Chem. Eng. 2019, 97, 2131-2136.

(21) Mattisson, T. Materials for Chemical-Looping with Oxygen Uncoupling. ISRN Chem. Eng. 2013, 2013, 1-19.

(22) Shulman, A.; Cleverstam, E.; Mattisson, T.; Lyngfelt, A. Chemical - Looping with Oxygen Uncoupling Using Mn/Mg-Based Oxygen Carriers - Oxygen Release and Reactivity with Methane. Fuel 2011, 90, 941-950.

(23) Jing, D.; Hermans, E. Y. S. I. M.; Leion, H.; Rydèn, M.; Mattisson, T.; Van Noyen, J.; Lyngfelt, A. In Manganese-Silica Combined Oxides as Oxygen Carrier for Chemical-Looping Combustion, 2nd International Conference on Chemical Looping, 2012.

(24) MohammadPour, N.; Azimi, G.; Leion, H.; Rydén, M.; Mattisson, T.; Lyngfelt, A. Investigation of Manganese-Iron Oxide Materials Based on Manganese Ores as Oxygen Carriers for Chemical Looping with Oxygen Uncoupling (CLOU). Energy Technol. 2014, 2, 469-479.

(25) Abad, A.; Gayán, P.; De Diego, L. F.; García-Labiano, F.; Adánez, J. Modelling Chemical-Looping Assisted by Oxygen Uncoupling (CLaOU): Assessment of Natural Gas Combustion with Calcium Manganite as Oxygen Carrier. Proc. Combust. Inst. 2019, 37, 4361-4369.

(26) Moldenhauer, P.; Hallberg, P.; Biermann, M.; Snijkers, F.; Albertsen, K.; Mattisson, T.; Lyngfelt, A. Oxygen-Carrier Development of Calcium Manganite-Based Materials with Perovskite Structure for Chemical-Looping Combustion of Methane. Energy Technol. 2020, 8, No. 2000069.

(27) Hallberg, P.; Jing, D.; Rydén, M.; Mattisson, T.; Lyngfelt, A. Chemical Looping Combustion and Chemical Looping with Oxygen Uncoupling Experiments in a Batch Reactor Using Spray-Dried CaMn1- XM XO3- $\delta(\mathrm{M}=\mathrm{Ti}, \mathrm{Fe}, \mathrm{Mg})$ Particles as Oxygen Carriers. Energy Fuels 2013, 27, 1473-1481.

(28) Goldyreva, E. I.; Leonidov, I. A.; Patrakeev, M. V.; Kozhevnikov, V. L. Thermodynamics of Oxygen in CaMnO3- $\delta$. J. Solid State Electrochem. 2013, 17, 3185-3190.

(29) Jing, D.; Snijkers, F.; Hallberg, P.; Leion, H.; Mattisson, T.; Lyngfelt, A. Effect of Production Parameters on the Spray-Dried Calcium Manganite Oxygen Carriers for Chemical-Looping Combustion. Energy Fuels 2016, 30, 3257-3268.

(30) Arjmand, M.; Hedayati, A.; Azad, A. M.; Leion, H.; Rydén, M.; Mattisson, T. CaxLa1-XMn1-YMyO 3- $\delta(\mathrm{M}=\mathrm{Mg}, \mathrm{Ti}, \mathrm{Fe}$, or $\mathrm{Cu})$ as Oxygen Carriers for Chemical-Looping with Oxygen Uncoupling (CLOU). Energy Fuels 2013, 27, 4097-4107.

(31) Hallberg, P.; Jing, D.; Rydén, M.; Mattisson, T.; Lyngfelt, A. Chemical Looping Combustion and Chemical Looping with Oxygen Uncoupling Experiments in a Batch Reactor Using Spray-Dried CaMn1- XM XO3- $\delta(\mathrm{M}=\mathrm{Ti}, \mathrm{Fe}, \mathrm{Mg})$ Particles as Oxygen Carriers. Energy Fuels 2013, 27, 1473-1481.

(32) Jing, D.; Mattisson, T.; Leion, H.; Rydén, M.; Lyngfelt, A. Examination of Perovskite Structure $\mathrm{CaMnO}-\delta$ with $\mathrm{MgO}$ Addition as Oxygen Carrier for Chemical Looping with Oxygen Uncoupling Using Methane and Syngas. Int. J. Chem. Eng. 2013, 2013, No. 679560 .

(33) Hallberg, P.; Källén, M.; Jing, D.; Snijkers, F.; Van Noyen, J.; Rydén, M.; Lyngfelt, A. Experimental Investigation of CaMnO3- $\delta$ Based Oxygen Carriers Used in Continuous Chemical-Looping Combustion. Int. J. Chem. Eng. 2014, 2014, No. 412517.

(34) Rydén, M.; Leion, H.; Mattisson, T.; Lyngfelt, A. Combined Oxides as Oxygen-Carrier Material for Chemical-Looping with Oxygen Uncoupling. Appl. Energy 2014, 113, 1924-1932.

(35) Tescari, S.; Agrafiotis, C.; Breuer, S.; De Oliveira, L.; NeisesVon Puttkamer, M.; Roeb, M.; Sattler, C. Thermochemical Solar Energy Storage via Redox Oxides: Materials and Reactor/Heat Exchanger Concepts. Energy Procedia 2014, 49, 1034-1043.

(36) Mishra, A.; Li, T.; Li, F.; Santiso, E. E. Oxygen Vacancy Creation Energy in Mn-Containing Perovskites: An Effective Indicator for Chemical Looping with Oxygen Uncoupling. Chem. Mater. 2019, 31, 689-698.
(37) Peña, M. A.; Fierro, J. L. G. Chemical Structures and Performance of Perovskite Oxides. Chem. Rev. 2001, 101, 1981-2017. (38) Ji, Q.; Bi, L.; Zhang, J.; Cao, H.; Zhao, X. S. The Role of Oxygen Vacancies of $\mathrm{ABO} 3$ Perovskite Oxides in the Oxygen Reduction Reaction. Energy Environ. Sci. 2020, 13, 1408-1428.

(39) Mastronardo, E.; Qian, X.; Coronado, J. M.; Haile, S. Fe-Doped CaMnO3 for Thermochemical Heat Storage Application. AIP Conf. Proc. 2019, 2126, No. 210005.

(40) Keller, M.; Leion, H.; Mattisson, $\mathrm{T}$. Use of $\mathrm{CuO} / \mathrm{MgAl} 2 \mathrm{O} 4$ and $\mathrm{La} 0.8 \mathrm{Sr} 0.2 \mathrm{FeO} 3 / \mathrm{c}-\mathrm{Al} 2 \mathrm{O} 3$ in Chemical Looping Reforming System for Tar Removal from Gasification Gas. AIChE J. 2016, 62, 38-45.

(41) Alonso, E.; Pérez-Rábago, C.; Licurgo, J.; Fuentealba, E.; Estrada, C. A. First Experimental Studies of Solar Redox Reactions of Copper Oxides for Thermochemical Energy Storage. Sol. Energy 2015, 115, 297-305.

(42) Abad, A.; Adánez-Rubio, I.; Gayán, P.; García-Labiano, F.; de Diego, L. F.; Adánez, J. Demonstration of Chemical-Looping with Oxygen Uncoupling (CLOU) Process in a $1.5 \mathrm{~kW}$ Th Continuously Operating Unit Using a Cu-Based Oxygen-Carrier. Int. J. Greenhouse Gas Control 2012, 6, 189-200.

(43) Rydén, M.; Jing, D.; Källén, M.; Leion, H.; Lyngfelt, A.; Mattisson, T. CuO-Based Oxygen-Carrier Particles for ChemicalLooping with Oxygen Uncoupling - Experiments in Batch Reactor and in Continuous Operation. Ind. Eng. Chem. Res. 2014, 53, 62556267.

(44) Kerskes, H. Thermochemical Energy Storage. Storing Energy 2016, 345-372.

(45) Tregambi, C.; Montagnaro, F.; Salatino, P.; Solimene, R. Directly Irradiated Fluidized Bed Reactors for Thermochemical Processing and Energy Storage: Application to Calcium Looping. AIP Conf. Proc. 2017, 1850, No. 090007.

(46) Humphries, T. D.; Møller, K. T.; Rickard, W. D. A.; Sofianos, M. V.; Liu, S.; Buckley, C. E.; Paskevicius, M. Dolomite: A Low Cost Thermochemical Energy Storage Material. J. Mater. Chem. A 2019, 7, $1206-1215$

(47) Imtiaz, Q.; Hosseini, D.; Müller, C. R. Review of Oxygen Carriers for Chemical Looping with Oxygen Uncoupling (CLOU): Thermodynamics, Material Development, and Synthesis. Energy Technol. 2013, 1, 633-647.

(48) Wu, S.; Zhou, C.; Doroodchi, E.; Nellore, R.; Moghtaderi, B. A Review on High-Temperature Thermochemical Energy Storage Based on Metal Oxides Redox Cycle. Energy Convers. Manage. 2018, 168, 421-453.

(49) André, L.; Abanades, S. Investigation of Metal Oxides, Mixed Oxides, Perovskites and Alkaline Earth Carbonates/Hydroxides as Suitable Candidate Materials for High-Temperature Thermochemical Energy Storage Using Reversible Solid-Gas Reactions. Mater. Today Energy 2018, 10, 48-61.

(50) Mattisson, T.; Lyngfelt, A.; Leion, H. Chemical-Looping with Oxygen Uncoupling for Combustion of Solid Fuels. Int. J. Greenhouse Gas Control 2009, 3, 11-19. 